\title{
Kepemimpinan Kepala Sekolah dan Dampaknya Terhadap Pengelolaan Pada SMA Tegar Kelana Suranadi
}

\author{
IndianiIndiani $^{1)}$, Dadi Setiadi ${ }^{2)}$, Untung Waluyo ${ }^{3)}$ \\ ${ }^{1,2,3}$ Magister Administrasi Pendidikan \\ Email: aindi9435@gmail.com
}

\begin{abstract}
One of the problems faced by school principals under the auspices of the foundation is that there is a dual leadership between the head of the foundation and the headmaster which causes administrative activities to be hampered so that the process of improving the quality of education in educational units led by the principal is hampered. The purpose of this study is to describe the principal's leadership style in carrying out his role as managerial. This research was conducted at Tegar Kelana West Lombok High School.This study uses a qualitative approach to the type of grounded theory. Data and data sources used are primary and secondary data with purposive sampling techniques, while for data collection using interviews, documentation and triangulation techniques. Data analysis uses the interactive model (interactive mode). This study describes the principal's leadership style and its impact on the management of Tegar Kelana High School principals, which refers to Permendiknas No. 19 of 2007 concerning Education Management Standards by the Primary and Secondary Education Unit and National Education Minister's Regulation no. 13 of 2007 and No. 28 of 2010 concerning Managerial Principals. The results of the study illustrate the leadership style of principals who tend to use selling styles and participating styles, which have an impact on less effective school management.
\end{abstract}

\section{Keywords: Leadership Style, Competence, Managerial, Principal.}

Abstrak:Permasalahan yang dihadapi oleh kepala sekolah yang berada di bawah naungan yayasan salah satunya adalah terjadinya dual kepemimpinan anatara ketua yayasan dengan kepala sekolah yang menyebabkan kegiatan administratif terhambat sehingga proses peningkatan kualitas mutu pendidikan pada satuan pendidikan yang dipimpin kepala sekolah menjadi terhambat. Tujuan penelitian ini untuk mendeskripsikan gaya kepemimpinan kepala sekolah dalam menjalankan peranannya sebagai manajerial. Penelitian ini dilakukan di SMA Tegar Kelana Lombok Barat. Penelitian ini menggunakan pendekatan kualitatif jenis grounded theory. Data dan sumber data yang digunakan adalah data primer dan sekunder dengan teknik purposive sampling, adapun dalam pengambilan data menggunakan teknik wawancara, dokumentasi dan triangulasi. Analisis data menggunakan model intraktif (interactive mode). Penelitian ini menggambarkan gaya kepemimpinan kepala sekolah dan dampaknya terhadap pengelolaan kepala sekolah SMA Tegar Kelana yang merujuk pada Permendiknas No. 19 Tahun 2007 tentang Standar Pengelolaan Pendidikan oleh Satuan Pendidikan Dasar dan Menengah dan Permendiknas No. 13 Tahun 2007 dan No. 28 Tahun 2010 Tentang Manajerial kepala sekolah. Hasil penelitian menggambarkan gaya kepemimpinan kepala sekolah cendrung menggunakan gaya selling dan gaya participating, yang berdampak pada pengelolaan sekolah yang kurang efektif.

Kata Kunci: Gaya Kepemimpinan, Kompetensi, Manajerial, Kepala Sekolah.

\section{PENDAHULUAN}

Mutu pendidikan merupakan salah satu persoalan yang sedang dan tetap dihadapi bangsa Indonesia pada setiap jenjang dan satuan pendidikan (Nur, et al.,
2016). Berbagai upaya telah dilakukan untuk meningkatkan mutu pendidikan, antara lain melalui berbagai pelatihan dan peningkatan kompetensi sumber daya manusia (SDM) disetiap jenjang dan satuan pendidikan, 
pengadaan bahan dan alat pembelajaran, perbaikan sarana dan prasarana pendidikan untuk meningkatkan mutu manajemen sekolah (Setiyati, 2014). Akan tetapi belum menunjukan peningkatan yang berarti. Peningkatan mutu pendidikan merupakan sasaran pembangunan di bidang pendidikan nasional dan merupakan bagian integral dari upaya peningkatan kualitas manusia secara menyeluruh (Sari, et al., 2016).

Faktor utama yang akan mendukung proses peningkatan kualitas mutu pendidikan adalah gaya kepemimpinan. Salah satu faktor yang paling menentukan berhasilnya proses belajar mengajar sampai pada mutu pembelajaran di sekolah adalah Kepala Sekolah (Danim (2007). Setiap pemimpin memiliki gaya atau cara yang berbeda dalam memengaruhi dan menggerakan bawahanya dalam organisasi yang dipimpinnya (Marks, et al., 2003). Kepala sekolah sebagai pemimpin mempunyai peranan yang sangat besar dalam mengembangkan satauan pendidikan (AlSafran, et al., 2014). Kepala sekolah harus memiliki gaya kepemimpinan yang mampu mempengaruhi dan menggerakan bawahannya demi tercapainya peningkatan kualitas pendidikan yang berdampak pada peningkatan mutu pendidikan, khususnya satuan pendidikan yang dikelolanya (Dinham, 2005).

Gaya kepemimpinan kepala sekolah merupakan gaya kemampuan dari seorang kepala sekolah dalam mempengaruhi dan menggerakkan bawahan padasuatu organisasi atau lembaga sekolah guna tercapainya tujuan sekolah.Pemilihan gaya kepemimpinan yang tepat akan memberikan motivasi kerja kepada bawahan, sehingga bawahan akan merasa puas. Sebaliknya tidak jarang kesalahan dalam pemilihan gaya kepemimpinan berakibat kegagalan kepemimpinan seseorang dalam sekolah dan berdampak pada mutu pendidikan sekolah tersebut.
Gaya kepemimpinan mengandung perinsip sebagai perwujudan tingkah laku seseorang pemimpin yang menyangkut kemampuan dalam memimpin dan biasanya akan membentuk suatu pola tertentu. Gaya kepemimpinan dalam mengelola satuan pendidikan yang tepat dilakukan saat ini adalah bukan gaya paksaan tapi menggunakan pendekatan komitmen yang didasari kebersamaan. Adapun ciri-ciri kepemimpinan yang dapat mendorong proses keberlangsungan sekolah sekolah yang efektif meliputi memiliki visi, percaya diri, mampu mengomunikasikan ide, dapat diteladani, mempunyai idealisme, inspiratif, kemampuan memengaruhi dan mampu mengargai perbedaan untuk dirubah menjadi suatu kekuatan bersama, kepala sekolah, guru, staf kayawan membangun kebersamaan untuk mewujudkan kualitas pendidikan yang menjadi tanggung jawabnya (Ekosiswoyo, R. 2007: 82).

Berkaitan erat dari kepemimpinan dan kemampuan manjaerial kepala sekolah yang berada di bawah naungan yayasan, peneliti telah melakukan penelusuran di lapangan, dengan melakukan observasi langsung dan mewawancarai kepala sekolah salah satu sekolah menengah atas swasta di Kabupaten Lombok Barat Kecamatan Narmada, yaitu di SMA Tegar Kelana Suranadi.

Berdasakan hasil studi lapangan di SMA Tegar Kelana Suranadi kepala sekolah dihadapkan dengan keadan peserta didik yang memiliki latar belakang kurang baik, tenaga kependidikan yang masih belum linier dengan mata pelajaran yang di ampuh, sarana prasarana kurang memadai, dan lokasi. Hal ini megakibatkan kepala sekolah memiliki banyak permasalahan dalam menjalankan perannya sabagai pemimpin sekolah sekaligus sebagai manajerial di sekolah. Permasalahanpermasalahan yang dihadapi oleh kepala sekolah adalah dengan keadaan sekolah yang berasal dari banyak kultur budaya yang berbeda.

Kepala sekolah harus menyesuaikan dengan latar belakang peserta didik, iklim sekolah, dan ditambah juga dengan tuntutan atau perintah dari yayasan yang menaungi sekolah. Hal ini menyebabkan terjadi dual kepemimpinan antara ketua yayasan dengan kepala sekolah, 
dikatakan dual kepemimpinan disebabkan oleh oprasional di sekolah SMA Tegar Kelana Suranadi harus berdasarkan ketua yayasan, yang menyebabkan beberapa kegiatan administratif sekolah terhambat. Terkait dengan permasalahan yang dihadapi kepala sekolah, peneliti sangat tertarik untuk melakukan penelitian terkait gaya kepemimpinan kepala sekolah dalam hal pelaksanaan fungsi manajerial di SMA Tegar Kelana Suranadi Lombok Barat.

\section{METODE PENELITIAN}

Penelitian ini menggunakan pendekatan kualitatif menurut (Creswell, 2008). Pendekatan kualitatif bertujuan untuk memperoleh pemahaman dan penafsiran secara mendalam tentang gayakepemimpinan kepala sekolah dalam menjalankan peranya sebagai manajerial yaitu: 1) planning (perencanaan); 2) organizing (organisasi); 3) motivating (penggerak); dan4) controlling (pengawasan)pada SMA Tegar Kelana Suranadi, Kecamatan Narmada Kabupaten Lombok Barat.Jenis penelitian ini menggunakan grounded theory.

Sumber data yang digunakan adalah data primer dan sekunder dengan teknik purposive sampling, dimana informan yang dipilih adalah pihak yang dianggap paling mengetahui dan memahami permasalahan dalam penelitian (Sugiyono, 2006). Teknik pengumpulan data menggunakan wawancara, dokumentasi dan triangulasi. Teknik analisis data menggunakan model intraktif (interactive mode)(Miles dan Huberman, 1992). Sedangkan dalam mengecek keabsahan data penelitian ini dilaksanakan dengan kredibilitas, transferbilitas dan dependibilitas.

\section{HASIL DAN PEMBAHASAN}

Sekolah sebagai organisasi yang bergerak dibidang pendidikan untuk mencapai tujuan atau mencapai keberhasilannya sangat ditentukan oleh gaya kepemimpinan kepala sekolah sebagai pemimpin tertinggi di dalam organisasi sekolah. Gaya kepemimpinan yang ideal adalah dengan menerapkan semua gaya kepemimpinan dengan sebaik mungkin, pada saat situasi yang mendukung dan memenuhi kebutuhan kinerja kepemimpinan itu sendiri. kepemimpinan itu penting dalam mengembangkan sekolah yang efektif dan inovatif, untuk dapat memfasilitasi kualitas mengajar dan belajar(Jacobson, et al., 2005).

Kepala sekolah SMA Tegar kelana secara keseluruhan cendrung menerapkan gaya kepemimpinan ke arah selling dan participating dalam melaksanakan fungsi manajerial yang merujuk pada PeraturanMenteri Pendidikan Nasional Nomor 13 Tahun 2007, Nomor 19 Tahun 2007 dan Nomor 28 Tahun 2010, tentang kemampuan manajerial kepala sekolah. Menurut John Beck dan Neil Yeager yang dikutip oleh Djokosantoso Moeljono (2003) gaya kepemimpinan selling dan participating dijelaskan sebagai berikut: (1) Selling (problemsolving/coarchig), seorang pemimpin yang mau melibatkan bawahan dalam pembuatan keputusan. Pemimpin bersedia membagi persoalan dengan bawahannya, dan sebaliknya persoalan dari bawahan selalu didengarkan serta memberikan penghargaan mengenai apa yang mereka perlukan; (2) Participating (depeloving/encouraging), Pemimpin yang bersedia memberikan kesempatan bawahan agar dapat berkembang dan bertanggungjawab serta memberikan dukungan yang sepenuhnya mengenai apa yang mereka perlukan.

Sejalan dengan penelitian yang dilakukan oleh Perni (2019) menyatakan bahwa kepala sekolah adalah sebagai orang yang menolong, menunjukkan ketegasan dan kehangatan, memberikan bimbingan, membangun hubungan saling mempercayai, memberikan penguatan, mendengarkan secara simpati serta menunjukkan sikap tanggap.

Wahjosumidjo memaparkan (2007) bahwa budaya sekolah merupakan sesuatu yang dibangun dari hasil pertemuan antara nilai-nilai (value) yang dianut oleh kepala sekolah sebagai pemimpin dengan nilai-nilai yang dianut oleh guru-guru dan para karyawan yang ada di sekolah. sedangkan menurut Riduwan (2010) lingkungan sekolah yang aman dan tertib, optimisme dan harapan /ekspektasi yang tinggi 
dari warga sekolah, kesehatan sekolah, dan kegiatan-kegiatan yang berpusat pada siswa (student centered activities) adalah contohcontoh budaya sekolah yang dapat menumbuhkan semangat belajar siswa.

Terdapat hubungan sebab/akibat, langsung dan tidak langsung antara gaya kepemimpinan kepala sekolah dan hasil sekolah. Yang tidak langsung adalah di mana gaya kepemimpinan kepala sekolah mempengaruhi lingkungan sekolah yang berdampak pada hasil sekolah.

Pemeliharaan lingkungan sekolah adalah tanggung jawab semua anggota di semua warga sekolah (termasuk kepala sekolah, guru, staf, siswa, dan semua pihak yang terkena dampak dan dipengaruhi oleh sekolah). Para pemangku kepentingan Pendidikan Indonesia juga perlu melakukan kegiatan tersebut (Setiawan, et al., 2019).

Apabila dilihat dari hasil wawancara dengan guru dan pegawai, kepala sekolah dalam menjalankan fungsi manajerial maka dapat dilihat lebih jelas gaya yang cenderung diterapkan oleh kepala sekolah SMA Tegar kelana Suranadi dalam menjalankan kepemimpinannya adalah sebagai berikut:

1. Gaya kepemimpinan kepala sekolah dalam menjalankan fungsi perencanaan

Proses perencanaan program kerja di SMA Tegar Kelana Suranadi, kepala sekolah cenderung menggunakan gaya kepemimpinan selling dan participating. Kepala sekolah dalam menjalankan fungsi perencanaan menggunakan gaya kepemimpinan selling, hal ini dapat dilihat dengan indikator kepala sekolah sebelum membuat perencanaan sekolah, terlebih dahulu ada pemberitahuan kepada guru dan pegawai bahwa akan ada rapat penyusunan program kerja sekolah. Kepala sekolah dalam menyusun program kerja selalu melibatkan guruguru dan pegawai, dengan memberikan pengarahan dan petunjuk yang jelas.
Penyusunan program sekolah dilakukan dengan cara pemberian tanggungjawab kepada masing-masing wakil kepala sekolah (wakasek) untuk menyelesaikan program sesuai dengan bidang garapannya masingmasing, kemudian setelah selesai kepala sekolah akan membuat tim penyusun program kerja, yang terdiri dari empat orang wakasek, guru dan pegawai lalu akan ada pemberitahuan rapat selanjutnya yang akan membahas tentang program kerja tersebut dengan memberi kepercayaan kepada para timpenyusun perencanaan untuk menyusun program yang sesuai dengan keadaan sekolah dan sesuai dengan kurikulum yang digunakan oleh SMA Tegar Kelana Suranadi.

Jika kepala sekolah mendapatkan persoalan, maka kepala sekolah tidak sungkan untuk membagi persoalan sekolah kepada bapak dan ibu guru maupun pegawai, terkait program kerja yang akandilaksanakan di sekolah terutama kepala sekolah terbuka tentang keuangan sekolah yang dikelola langsung oleh yayasansehingga tim perumus menyusun program sesuai dangan dana yang dikasih oleh yayasan. Sebaliknya jika ada guru dan pegawai yang mendapatkan persoalan dalam penyusunan program kerja, maka kepala sekolah dengan senang hati mendengarkan permasalahan yang dihadapi guru maupun pegawai.

\begin{tabular}{llr}
\multicolumn{2}{c}{ Selain } & gaya selling, kepala \\
dalam & menjalankan & fungsi \\
perencanaan & juga menggunakan & gaya
\end{tabular} kepemimpinan perticipating, hal ini dilihat dari indikator berikut ini: Kepala sekolah melibatkan hampir semua guru dan pegawai berpartisipasi dalam menyusun dan menentukan program kerja apa saja yang akandijalankan di sekolah sehingga tujuan yang telah ditetapkan dapat tercapaiatau keputusan tidak sepihak tetapi mendengar pendapat dari bawahan.

Kepala sekolah pada saat pelaksanaan rapat penyusunan program kerja sekolah terlebih dahulu memberikan kesempatan kepada wakasek untuk memaparkan program-program yang telah mereka susun, 
Terakreditasi Peringkat 5 (No. SK: 85/M/KPT/2020)

lalu kemudian memberikan kesempatan kepada ibu danbapak guru serta pegawai lain untuk memberikan ide-ide mengenai program kerja yang akandilaksanakan dan program kerja yang kiranya kurang sesuai dengan keadaan sekolah dan pendanaan. Tidak lupa kepala sekolah juga selalu memberi pengarahanyang jelas kepada guru dan pegawai. Apabila akan ada pembatalan program kerja oleh kepala sekolah karena program tersebut dianggap kurang mendukung dalam perbaikan sekolah dan kurangnya dana, maka akan ada pemberitahuan oleh kepala sekolah kepada tim penyusun program sekolah sebelum program tersebut dibatalkan, artinya tidak ada pembatalan program secara sepihak.

Program kerja yang ideal adalah suatu program yang tidak hanya menyentuh manajerial puncak tetapi juga pada warga dibawahnya (karyawan, siswa, dan masyarakat). Pekerjaan perumusan program kerja bukanlah pekerjaan mudah karena menyangkut kebutuhan orang banyak terutama konsumen internal atau peserta didik. Oleh karena itu, sebagai kepala sekolah tentunya memiliki cara tersendiri dalam memengaruhi warga di bawahnya sehingga ikut serta mengambil andil dalam perumusan perencanaan program sekolah sehingga sesuai dengan kebutuhan orang banyak khususnya kebutuhan peserta didik. Cara inilah yang disebut dengan gaya, karena setiap kepala sekolah tentunya meliliki gaya tersendiri sebagai pemimpin sekolah demi mewujutkan tujuan yang telah ditetapkan.

2. Gaya kepemimpinan kepala sekolah dalam menjalankan fungsi pengorganisasian

Selain perencanaan yang menjadi perhatiaan penting oleh kepala sekolah adalah pengorganisasian karena fungsi ini perlu dilakukan untuk mewujudkan struktur organisasi sekolah, uraian tugas tiap bidang, wewenang dan tanggung jawab menjadi lebih jelas dan penentuan sumber daya manusia (SDM) dan materi yang diperlukan. Sekolah sebagai lembaga pendidikan yang memiliki tujuan sesuai dengan arahan pendidikan nasional harus memiliki struktur organisasi sekolah yang jelas. Struktur organisasi sekolah sangatlah penting untuk terlaksananya proses kegiatan belajar mengajar karena berubungan dengan masalah tata kerja personal sekolah.

Struktur organisasi merupakan gambaran hubungan dalam menjalankan tugas dan fungsi serta peran dari masingmasing bagian dalam sebuah organisasi. Pembagian tugas yang jelas akan lebih memudahkan dalampelaksanaan tugas dalam sebuah organisasi khususnya di sekolah. Hasil dari prosespengorganisasian atau menyangkut penentuan pekerjaan, pembagian kerja,penetapan mekanisme untuk mengkoordinasikan kegiatan adalah strukturorganisasi. Struktur organisasi sebagai perwujudan yang menunjukkanhubungan dalam menjalankan sebuah fungsi dan peran darimasing-masing bagian dalam sebuah organisasi. Tugas dan peran itu nantinya akan mempermudah sebuah kerjasama yang jelas dan terarahdalam mencapai tujuan yang telah diharapkan oleh sekolah.

Berdasarkan temuan penyusunan struktur organisasi di SMA Tegar Kelana Suranadi, kepala sekolah cenderung menggunakan gaya kepemimpinanparticipating. Hal ini dapat dilihat dari indikataor kepala sekolah selalu melibatkan guru dan pegawai berpartisipasi dalam pembentukan struktur organisasi dengan cara setiap guru dan pegawai diberikan tanggungjawab sesuai dengan bidang dan kemampuan masing-masing. Contohnya guru ditugaskan dan diberi tanggungjawab sebagai wakil kepala sekolah bagian kurikulum karena dipandang mampu dan akan bertanggungjawab atas amanah yang diberikan oleh kepala sekolah, dan guru ditugaskan sebagai kepala laboraturium IPA karena sesuai dengan bidangnya. Hal ini 
Terakreditasi Peringkat 5 (No. SK: 85/M/KPT/2020)

sesuai dengan teori gaya kepemimpinan participating yang dikemukakan oleh John Beck dan Neil Yeager yang dikutip olehMoeljono, D. (2003:34)bahwa pemimpin yang bersedia memberikan kesempatan bawahanagar dapat berkembang dan bertanggungjawab sertamemberikan dukungan yang sepenuhnya mengenai apa yangmereka perlukan.

$$
\text { Gaya kepemimpinan }
$$

participating yang dilakukan oleh kepala sekolah dapat dilihat juga dari adanya pembagian tugas antara guru dan kariawan pada saat kegiatan berlangsung, semisal pembentukan panitia pelaksanaan evaluasi hasil belajar semua guru dan pegawai terlibat berpartisipasi dalam pelaksanaan evaluasi hasil belajar, pembentukan panitia akreditasi sekolah juga semua guru dan pegwai terlibat dengan diberi tugas dan tanggung jawab masing-masing.

\section{Gaya}

kepemimpinanparticipating yang dilakukan oleh kepala sekolah juga bisa dilihat dengan adanya pelibatan guru dan pegawai ikut serta dalam dalam pelatihan-pelatihan yang diadakan oleh dinas pendidikan Prov. NTB, meskipun secara khusus yang diadakan dari sekolah belum ada. Karena kepemimpinan participating tidak hanya melibatkan bawahan dalam pembagian tugas melainkan kepala sekolah memberikan kesempatan kepada guru dan pegawai agar dapat berkembang sesuai dengan kemampuan dan bidangnya masingmasing.

Pembentukan struktur organisasi yang dilakukan oleh kepala sekolah dengan cara pemberian tugas dan tanggung jawab kepada guru dan pegwai dengan mengikutsertakan guru dan pegawai secara langsung dalam sebuah rapat pembentukan struktur organisasi sekolah dan kepala sekolah selalu berusaha meminta dan mempergunakan saran-saran dari guru-guru dan pegwai yang mengikuti rapat struktur organisasi sekolah atau kegiatan rapat lainnya, akan tetapi dalam pengambilan keputusan tetap berada pada kepala sekolah, sejalan dnegan teori yang dikemukakan oleh Robert House dalam (Thoha, 2007:296), Kepemimpinan Partisipasif merupakan gaya kepemimpinan dimana pemimpin berusaha meminta dan mempergunakan saran-saran dari para bawahannya, akan tetapi dalam pengambilan keputusan masih tetap berada pada pemimpin.

Kondisi seperti ini layaknya dipertahankan oleh sekolah karena dengan adanya pelibatan secara langsung guru dan pegawai dalampembagian tugas-tugas dan wewenang serta tanggungjawab diantara guru

dan pegawai, akan tercipta suatu organisasi sekolah yang dapat digerakkaansebagai satu kesatuan dalam rangka mencapai tujuan yang telah ditetapkan.Meskipun dalam pengambilan keputusan final tetap kepala sekolah, akan tetapi nilai tambahnya selalu ada pelibatan guru dan pegwai sehingga tidak ada keputusan secara sepihak oleh kepala sekolah.

3. Gaya kepemimpinan kepala sekolah dalam menjalankan penggerakan/pengembangan (motivating/actuating)

Kepala sekolah cenderung menggunakan gayapartisipating dan selling dalam proses penggerakan bawahan, yang berpola hubungan kerja sama. Hal ini dapat dilihat dari kepala sekolah memberikan perhatian kepada bapak dan ibu guru serta semua karyawan untuk dapatmelaksanakan tugas masing-masing dengan baik. Pengarahan ini dilakukan pada saat rapat awal tahun pelajaran baru, rapat kegiatan, dan pembinaan. Pengarahan yang dilakukan kepala sekolah lebih bersifat umum, maksudnya pengarahan dilakukan secara bersama-sama untuk semua guru dan pegawai. Gaya kepemimpinan kepala 
sekolah yang berpola hubungan kerja sama yang dilakukan kepala sekolah juga dapat dilihat dari indikator bahwa ketika rapat, kepala sekolah secara tidak langsung sebagai penggerak berupa pemberian pengarahan pembagian tugas mengajar kepada guru-guru dan penentapan wali kelas, pemberian motivasi dan pembinaan sehingga dengandemikian mereka bisa meningkatkan kinerjanya dan dapat mencapaitujuan organisasi yang sesuai dengan visi dan misi yang sudah ditetapkansesuai target.

Penggerakan yang dilakukan oleh kepala sekolah SMA Tegar kelana Suranadi selain dalam proses pembagian tugas dan proses pembelajaran di kelas penggerakan guru dan pegawai dilakukan oleh kepala sekolah pada saat akan dilaksanakan setiap kegiatan sekolah semisal upacara bendera, pelaksanaan imtaq setiap hari jumat, kegiatan yang berhubungan dengan kepengawasan dari dinas, tentunya penggerakan yang dilakukan kepala sekolah tidak terlepas dari pola kerja sama antar guru dan pegawai lainnya. Kepala sekolah juga sering memberikan motivasi dan semangat kepada para guru dan pegawai pada saat jam istirahat, memotivasi guru dan pegawai ditengah keadaan sekolah yang sangat terbatas baik dari segi daya dukung pembelajaran, keterbatasan guru dan pegawai serta keadaan peserta didik yang memiliki semangat belajar rendah.

Jadi, proses menggerakkan semua guru dan pegawai yang telah dilakukanoleh kepala sekolah dengan gaya yang berpola mementingkan hubungankerja sama adalah sebagai pemicu bagi guru dan pegawai untuk bekerja dan bertanggungjawab atas tugas yang telah diberikan secara baik benar. Akan tetapi dalam proses penggerakan guru dan pegawai oleh kepala sekolah tidak dilakukan secara maksimal, karena masih ada guru dan pegawai yang tidak menjalankan tugas dengan baik dan benar. Oleh karena itu kepala sekolah masih harus meningkatkan fungsinya sebagai penggerak dengan cara meningkatkan komunikasi dan pendekatan terhadap guru dan pegawai,memberi penghargaan kepada guru dan pegawai yang berprestasi,sehingga semua masyarakat sekolah di SMA Tegar Kelana Suranadi dapat bekerja lebih semangat sehingga tujuan sekolah dapat tercapai.

4. Gaya kepemimpinan kepala sekolah dalam menjalankan fungsi pengawasan

Proses pelaksanaan pengawasan (controlling) terhadap guru, pegawai dan peserta didik dilaksanakan, oleh kepala sekolah SMA Tegar Kelana Suranadi secara langsung maupun tidak langsung. Pengawasan secara langsung yaitu dengan melihat secara langsung kegiatan guru, pegawai dan peserta didik, misalnya melalui kegiatan melihat langsung keadaan kelas, berkeliling disekitar halaman sekolah selama proses pembelajaran berlangsung. Pengawasan secara langsung hampir dilakukan setiap hari melihat keadaan guru yang kurang sehingga peserta didik jarang diawasi jadi kepala sekolah yang akan terjun langsung untuk mengawasi peserta didik, melihat keadaan peserta didik ketika belajar tidak akan betah di kelas, ada saja alasannya untuk pergi keluar dari kelas mereka. Meskipun pengawasan yang dilakukan terhadap proses pembelajaran secara rutin tidak dilakukan.

Dalam proses pengawasan, kepala sekolahcenderung menggunakan gaya kepemimpinan participating yakni melakukan pengawasan secra bersama dengan guru dan pegawai, semisal kepala sekolah menugaskan guru olahraga untuk menjaga pintu gerbang sekolah agar peserta didik, tidak keluyuran keluar pada saat jam pelajaran berlangsung, terkadang juga kepala sekolah meminta guru yang tidak memiliki jadwal pelajaranuntuk bergantian menjaga pintu gerbang. Dalam pengawasan maupun 
evaluasi selalu dilakukan secara bersama-sama kepala sekolah dengan guru dan pegawai, semisal pada saat akan dilaksanakannya evaluasi pembelajaran seperti ujian akhir sekolah, dialkukan secara bersamasama. Pengawasankepala sekolah tidak bersifat rutin, sehingga hasil dari pengawasan yang dilakukan kepala sekolah tidak maksimal, seharusnya sesuai dengan prinsip-prinsip pengawasan yaitupengawasan harus dilakukan secara terus-menerus sehingga dapatdiketahui perkembangan kinerja atau pekerjaan yang dilakukan setiapanggota organsiasi.

Pengawasan terhadap kinerja guru dan pegawai juga dilakukan oleh kepala sekolah dengan gaya participating dengan indikator sebagai berikut: dalam melakukan pengawasan guru, kepala sekolah biasanya akan disampaikan pada saat bersama dengan guru dan pegawai pada waktu jam istirahat.

\section{KESIMPULAN}

Gaya yang diterapkan kepala sekolah dalam kepemimpinanya di SMA Tegar Kelana Suranadi cendrung menggunakan gayaselling dan participating. Gaya kepemimpinan selling disini dapat dilihat bahwa kepala sekolah mengutamakan kerjasama yang baik sekaligus mau melibatkan bawahan dalam pembuatan keputusan. Kepala sekolah bersedia membagi persoaalan dengan bawahannya dan sebaliknya persoalan bawahann juga didengarkan dengan memberikan nasehat dan solusi. Sedangakan gaya kepemimpinan participating, kepala sekolah memberikan kesempatan kepada bawahan supaya lebih berkembang dan bertanggung jawab serta memberikan dukungan kepada guru dan pegawai untuk berkembang, seperti melibatkan guru-guru dalam setiap pelatihan, mempercayakan tugas kepada guru, dan memberikan guru dan pegawai kebebasan untuk berkreatifitas sesuai bidang dan kemampuannya, dengan tetap berpatokan pada kepala sekolah sebagai penentu keputusan.

\section{SARAN}

Kepala sekolah sebagai pemimpin sekolah semestinya tetap menyesuaikangaya kepemimpinan dengan situasi dan kondisi sekolah yang berada di bawah naungan yayasan, situasi dan kondisi peserta didik, guru dan pegawai sepanjang tidak melenceng dari pekerjaan yang dilakukanagar tujuan bisa berjalan sesuai dengan yang telahditetapkan.

\section{DAFTAR PUSTAKA}

Creswell, J. W. (2008). Educational Research (Planning, Conducting, and Evaluating Quantitative and Qualitativer Research) Third Edition. Canada: New Jersey.

Danim, S. Suparno,(2009) Manajemen dan Kepemimpinan Transformasional kepala sekolah. Jakarta: Rineka Cipta.

Dinham, S. (2005). Principal leadership for outstanding educational outcomes. Journal of educational administration

Ekosiswoyo, R. (2007). "Kepemimpinan kepala sekolah yang efektif kunci pencapaian kualitas pendidikan". Jurnal Jurnal Ilmu Pendidikan. 14, (2), 76-82.

Jacobson, S. L., Day, C., \& Leithwood, K. (2005). Understanding successful principal leadership: Progress on a broken front. Journal of educational administration.

Marks, H. M., \& Printy, S. M. (2003). Principal leadership and school performance: An integration of transformational and instructional leadership. Educational administration quarterly, 39(3), 370397.

Miles, B. W \& Huberman, M. (1992). Qualitatif Data Analysis: A Methods Sourcebook Third Edition. Arizona State University: USA

Moeljono, D. (2003). Beyond Leadership 12 Konsep Kepemimpinan. Jakarta: Gramedia.

Nur, M., Harun, C. Z., \& Ibrahim, S. (2016). Manajemen Sekolah Dalam Meningkatkan Mutu Pendidikan Pada Sdn Dayah Guci Kabupaten Pidie. 
Jurnal Administrasi Pendidikan: Program Pascasarjana Unsyiah, 4(1).

Peraturan Menteri Pendidikan Nasional RI No. 13. (2007). Tentang Standar Kepala Sekolah/Madrasah. Badan Standar Nasional Pendidikan (BSNP). Jakarta.

Peraturan Menteri Pendidikan Nasional RI No. 19. (2007). Tentang Standar Pengelolaan Pendidikan oleh Satuan Pendidikan. Badan Standar Nasional Pendidikan (BSNP). Jakarta.

Peraturan Menteri Pendidikan Nasional RI No. 28. (2010). Tentang Penugasan Guru sebagai Kepala Sekolah. Badan Standar Nasional Pendidikan (BSNP). Jakarta

Perni, N. N. (2019). Tantangan Dalam Manajemen Sekolah Dasar. Adi Widya: Jurnal Pendidikan Dasar, 3(1), 37-48.

Riduwan. 2010. Metode dan Teknik Menyusun Proposal Penelitian. Bandung: Alfabeta

Sari, A., Purwanti, E., \& Masrur, M. (2016). Strategi Kepala Sekolah Dalam Meningkatkan Mutu Pembelajaran Di Smp Nurul Islam Kelurahan Garuntang Kecamatan Bumi Waras Kota Bandar Lampung: Indonesia. Journal Manajemen Pendidikan Islam Al Idarah, 1(1), 1-9.

Setiawan, H., Afriani, R., \& Dhae, M. D. (2019). Building the framework of local Adiwiyata schools in Sintang District, West Kalimantan Province. JPBI (Jurnal Pendidikan Biologi Indonesia), 5(3), 471-480.

Setiyati, S. (2014). Pengaruh kepemimpinan kepala sekolah, motivasi Kerja, dan budaya sekolah terhadap kinerja guru. Jurnal Pendidikan Teknologi dan Kejuruan, 22(2), 200-206.
Sugiyono. (2006). Metode Penelitian Pendidikan; Pendekatan Kuantitatif dan Kualitatif dan R\&D. Bandung: Alfabet.

Thoha, M. (2007). Kepemimpinan Dalam Manajemen. Jakarta : PT. Raja Grafindo Persada.

Wahjosumidjo. 2005. Kepemimpinan Kepala Sekolah Tinjauan Teoritik dan Permasalahannya.Jakarta: Rajawali Press 